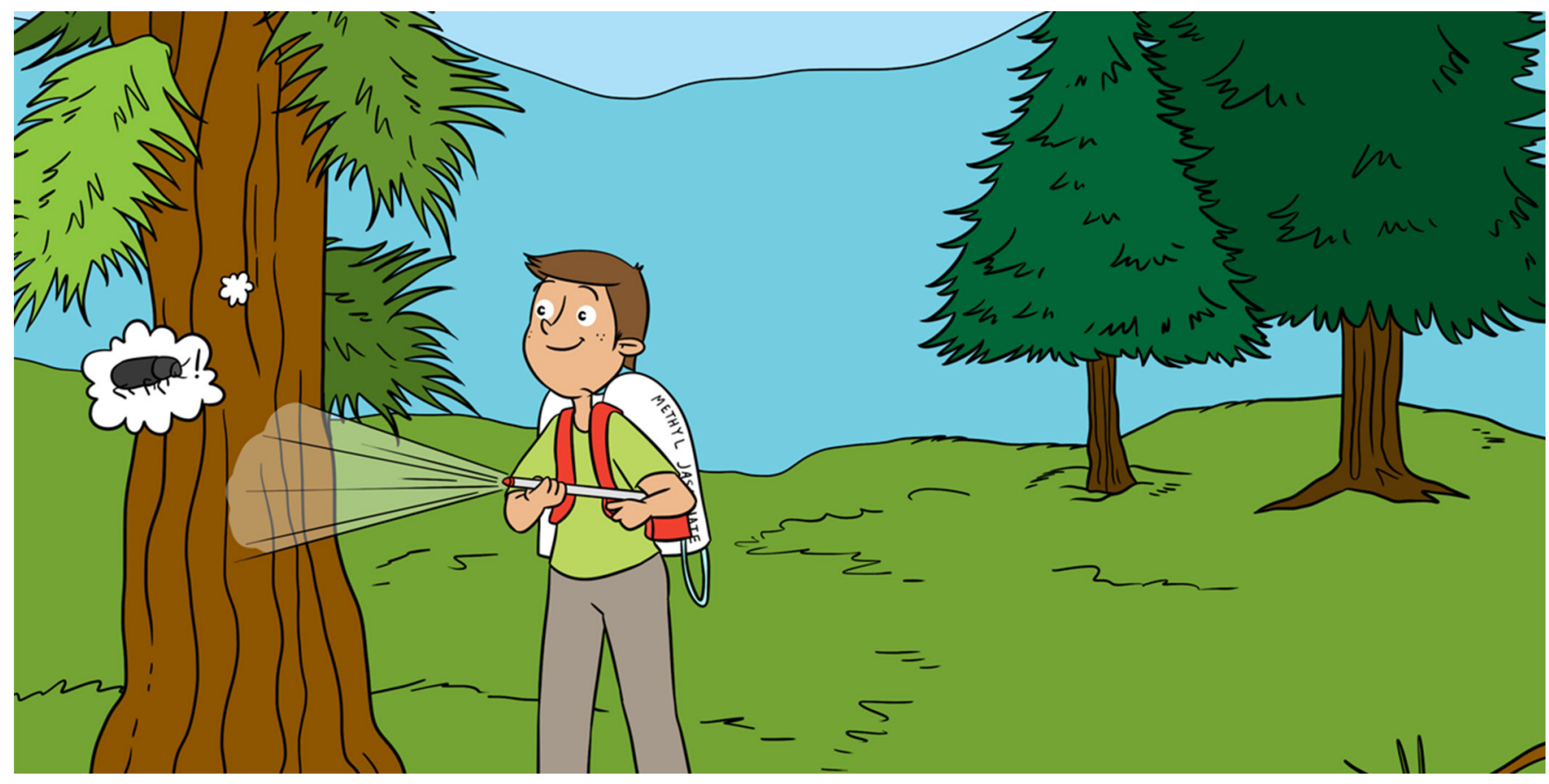

\title{
A BATTLE FOR THE FOREST: SPRUCE CASTLES AND BARK BEETLE ATTACKS
}

\section{Melissa H. Mageroy “ and Paal Krokene}

Division of Biotechnology and Plant Health, Norwegian Institute of Bioeconomy Research, Ås, Norway

YOUNG REVIEWERS:

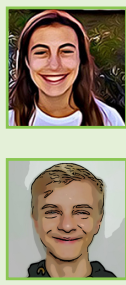

GWEN

AGE: 13

JUSTUS

AGE: 14
Conifers, like spruce and pine, are the most common trees found in the huge boreal forest that stretches around the northern part of the world. Over their long lifetime of 500 years or more, conifers face many threats. One deadly threat is an invasion by tree-killing insects, such as bark beetles. Like medieval castles, conifer trees have many ways to defend themselves. Still, sometimes large armies of bark beetles and their fungal partners can defeat these defenses and kill millions of trees. We found that spraying spruce trees with a natural chemical, called methyl jasmonate, can boost tree defenses and protect the trees against a bark beetle attack. Today, increasing temperatures and changing rain patterns help bark beetles be more successful in killing trees. Therefore, it is important that we understand how trees defend themselves and how we can help to protect them against insect invaders. 
Figure 1

Boreal forests. Conifers dominate the boreal forest that covers the northern parts of North America, Europe, and Asia. (A) People walking in a planted conifer forest in Ås, Norway. (B) A waterfall pours out of a conifer forest in British Columbia, Canada.

\section{CONSTITUTIVE} DEFENSES

Are ways trees have to protect themselves that are always present.

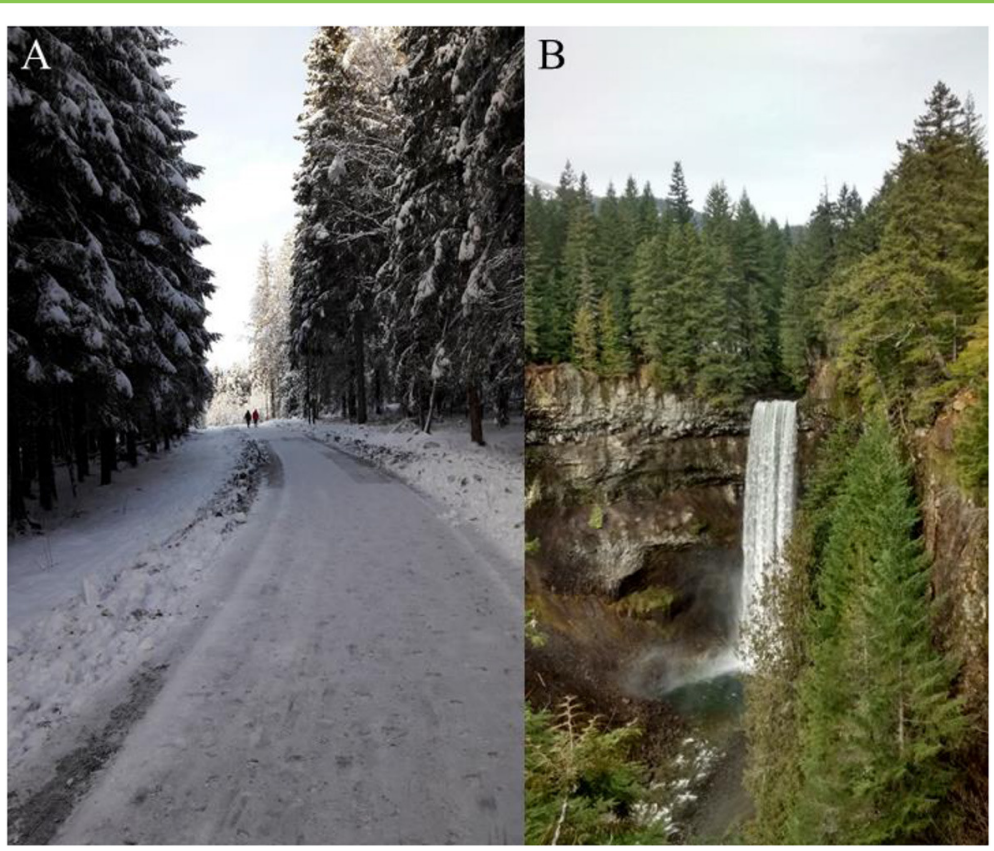

Figure 1

\section{CONIFER FOREST}

Have you ever walked in a forest among tall trees? The boreal forest is the world's largest forest and makes up about one-third of all forests. The boreal forest stretches around the northern part of the globe and can be found in places like Canada, Scandinavia, and Russia (Figure 1). This forest is home to many types of animals, like moose and bears, as well as plants, like moss and trees. Conifers are the most common trees found in boreal forests. Conifers are woody plants, such as pine, spruce, and fir trees, which produce cones with seeds. They are also commonly used as Christmas trees.

Conifers are amazing because they grow taller and larger than any other tree. They are also some of the oldest living organisms on earth and can live for hundreds and even thousands of years. The oldest known living conifer is a Great Basin bristlecone pine called Methuselah [1]. Methuselah is 4,850 years old. Over their long lifetime, conifers face many threats, such as stormy weather and attacks by animals. Unlike humans, trees cannot go inside during a snowstorm or run away when something is trying to eat them. Instead, they must stand still, while they protect and defend themselves as best they can.

\section{CONIFER CASTLES}

Like medieval castles, conifer trees have several layers of defenses [2]. Conifers and other plants have two main types of defenses: those that are always present, known as constitutive defenses, and those 
Figure 2

Conifer castles and bark beetle attacks. Like medieval castles, conifer trees have many defenses that protect them from invaders. (A) The outer bark, like a fortress wall, is a tough barrier to invaders. Inside the outer bark, hard stone cells and poisonous chemicals in resin pipes make up a second layer of defense. (B) If a bark beetle is able to enter a tree, she digs long vertical passageways in the inner bark and lays her eggs. When the eggs hatch, her babies feed on the bark making new horizontal tunnels. (C) The beetles carry tiny fungi into the tree. These fungi help defeat the tree's defenses.

\section{INDUCIBLE} DEFENSES

Are ways trees have to protect themselves, but that the tree makes after an attack.

\section{TERPENES}

Are toxic chemicals that conifers make to defend themselves.

\section{FUNGI}

Are organisms that get their energy by breaking down other organisms, just like animals do.

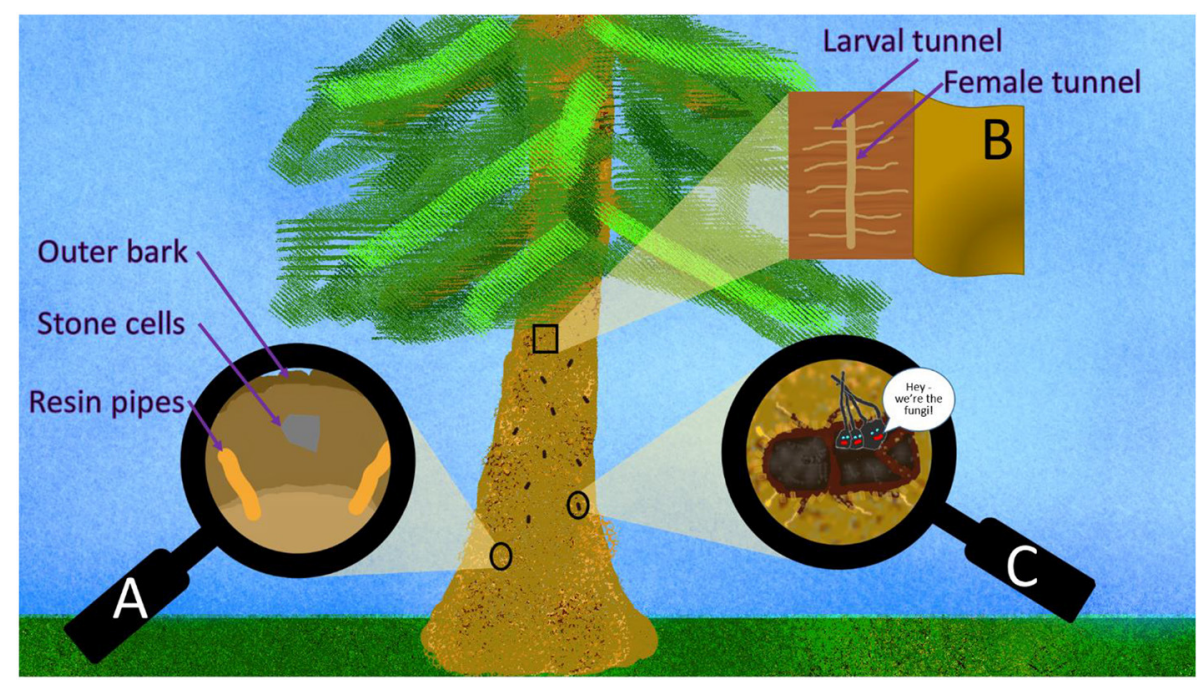

Figure 2

that appear only when the tree feels threatened, known as inducible defenses. One constitutive defense is the bark. The outer bark is a tough barrier, much like the outer walls of a fortress (Figure 2A). An insect that attacks a tree must get through this wall to reach the tasty, nutritious parts inside.

A second constitutive defense that conifers have is stone cells (Figure 2A). These hard cells act like small boulders, making it difficult for insects to chew their way through the bark. A third defense is small pipes inside the bark that are filled with chemicals called terpenes (Figure 2A). Terpenes give pine trees their "piney" smell. Terpenes also form resin, the sticky goop that you get on your hands if you cut a conifer tree. Terpenes are poisonous to insects. In addition, resin is sticky and can trap insects and stop them from entering the tree. Some resin pipes are always present, but the tree can make many more when it is cut or attacked by an insect.

\section{BARK BEETLE ATTACK}

Did you know that tiny beetles, no bigger than grains of rice, can kill a healthy conifer tree [3]? One beetle alone cannot kill a tree, but like an army, bark beetles work together to invade the tree. Hundreds of beetles can dig under the bark of a single tree and lay their eggs (Figure 2B). When the eggs hatch, the larvae (baby beetles) eat the tree to help them grow into adult beetles.

The beetles also get help from fungi to defeat the tree's defenses. Like a horse and rider, the bark beetle carries the fungi through the tree's tough outer bark (Figure 2C). Once inside the bark the fungi get off the "horse" and grow into the tree. Here the fungi eat some of the poisonous chemicals the tree has made to defend itself. By getting 
Figure 3

How methyl jasmonate can prevent bark beetle invasion. Trees sprayed with water are not prepared for a bark beetle attack. The bark beetle can defeat the tree's constitutive defenses and enter the bark. Spraying trees with methyl jasmonate causes the trees to make new pools of poisonous resin, preparing them for battle. When the bark beetle tries to enter, it is flushed out or trapped by the poisonous, sticky resin.

METHYL

\section{JASMONATE}

Is a signal made by plants when they are being eaten or cut.

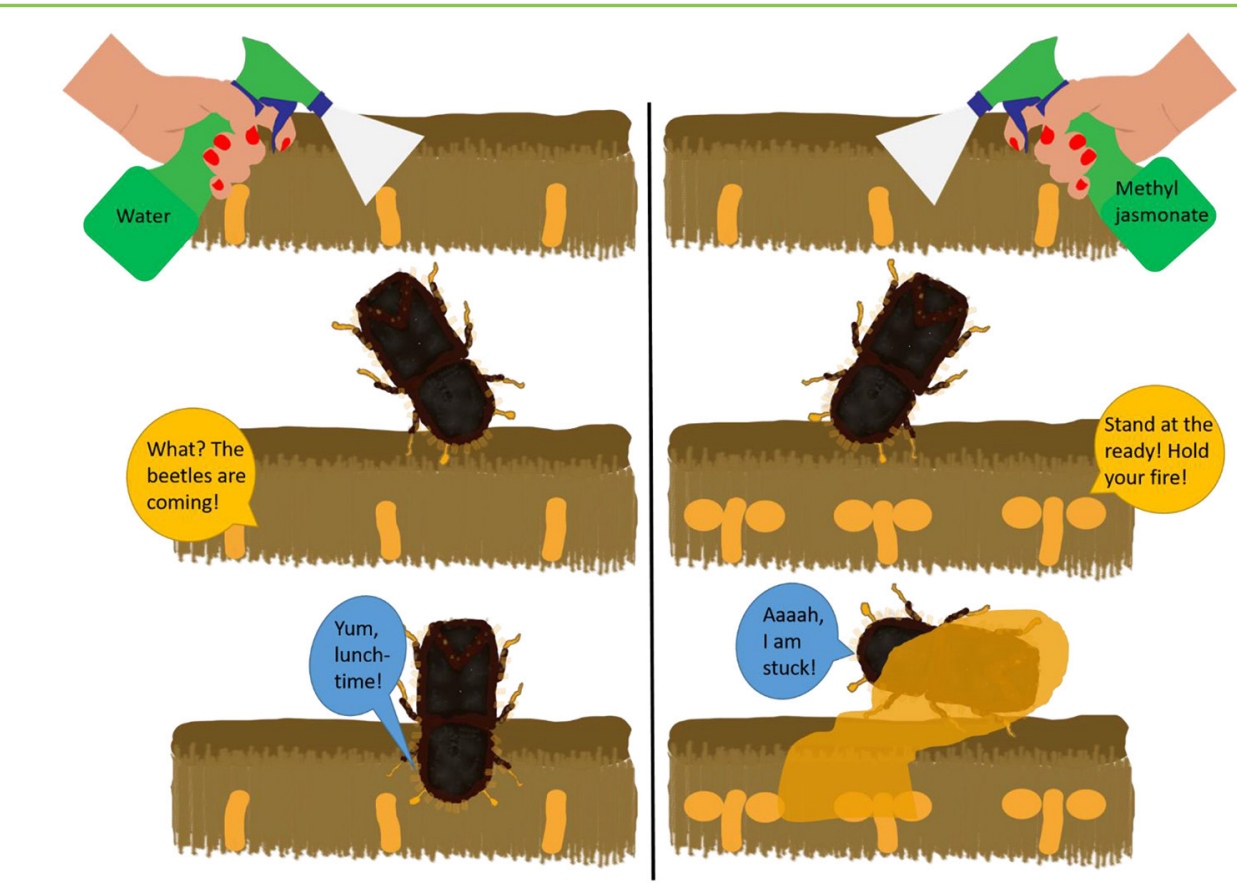

Figure 3

rid of the poison, the fungi make it easier for bark beetle larvae to grow. The fungi also make the tree weaker by killing tissues and taking nutrients from the tree. If the tree's defenses cannot stop the beetles and the growth of the fungi, the tree will eventually die.

\section{HELPING CONIFER TREES TO FORTIFY THEIR CASTLES}

We have found a way to help conifer trees boost their defenses and perhaps win the battle against bark beetles. We do this by spraying trees with a natural chemical made by plants. The chemical is called methyl jasmonate (meth-ill jazz-mon-ate) [4]. Methyl jasmonate is a signal that plants release into the air to tell surrounding plants, "I am under attack!" Spraying the bark of trees with methyl jasmonate is like sending a message to the trees saying, "Get prepared to fight! The bark beetles are coming!" (Figure 3).

We worked on a conifer species called Norway spruce, which is very common in Europe. We sprayed 20 trees in a forest with methyl jasmonate and 20 trees with water, as a control treatment [5]. We then waited 35 days for a bark beetle attack to begin. After another 30 days, we compared the trees sprayed with methyl jasmonate or water to see which trees bark beetles successfully invaded (Figure 3). By peeling away the outer bark, we could see that not a single bark beetle had laid eggs in trees sprayed with methyl jasmonate. This was very different from the trees sprayed with water. Most of the water-treated trees had beetle eggs in the bark and 11 of the 20 trees were killed by the beetles. 


\section{WHY ARE TREES SPRAYED WITH METHYL JASMONATE BETTER ABLE TO DEFEND THEMSELVES?}

One reason trees sprayed with methyl jasmonate are better at fighting against bark beetles is that sprayed trees make more of the poisonous resin (Figure 3) [3]. When the bark beetles try to dig into the bark, the sticky resin flows out and trap the beetles. Another reason sprayed trees are stronger is that they can more quickly activate their defenses. This is like having back-up troops. These troops are already trained for battle and can begin to fight immediately, which is better than having to train new troops before sending them out to fight.

The way spruce trees respond to methyl jasmonate is similar to what happens in your body when you get a vaccination. From the vaccination, your immune system gets information and remembers which viruses to watch out for so you will not get sick. Methyl jasmonate is a signal that helps trees remember to watch out for bark beetles.

\section{WHY IS OUR WORK IMPORTANT?}

Most of the time, bark beetles and conifer trees live in harmony in the forest. However, higher temperatures and increased drought stresses conifer trees. This makes the trees more vulnerable to bark beetle attacks [6]. In places like Colorado and the Czech Republic, bark beetles are killing millions of conifer trees $[7,8]$. The death of so many trees is bad in many ways. One problem is the loss of timber needed for building houses, schools, and other buildings. This also results in the loss of money for companies that cut trees and sell timber. The death of so many trees can also be bad for the environment we all depend on. Living, growing trees provide us with oxygen to breathe and are home for many types of animals. If we can understand how conifer trees defend themselves and help them fight against bark beetles, we can protect our forests and our environment.

\section{CONCLUSION}

Conifer trees are very important in the boreal forest. Because trees cannot run away from tree-eating insects, trees have many ways to defend themselves. Still, tiny bark beetles can get together and defeat tree defenses. These bark beetles sometimes kill millions of trees. We are trying to find ways to help conifer trees fight against bark beetles. In the future, we hope to find other tools, like methyl jasmonate, that help conifers fight bark beetle attacks and not lose the battle in the forest. 


\section{ORIGINAL SOURCE ARTICLE}

Mageroy, M. H., Christiansen, E., Långström, B., Borg-Karlson, A. K., Solheim, H., Björklund, N., et al. 2020. Priming of inducible defenses protects Norway spruce against tree-killing bark beetles. Plant Cell Environ. 43:420-30. doi: 10.1111/pce.13661

\section{REFERENCES}

1. Brown, P. M. Oldlist. Rocky Mountain Tree-Ring Research. Available online at: http://www.rmtrr.org (accessed August 25, 2020).

2. Franceschi, V. R., Krokene, P., Christiansen, E., and Krekling, T. 2005. Anatomical and chemical defenses of conifer bark against bark beetles and other pests. New Phytol. 167:353-76. doi: 10.1111/j.1469-8137.2005.01436.x

3. Krokene, P. 2015. "Conifer defense and resistance to bark beetles," in Bark Beetles: Biology and Ecology of Native and Invasive Species, eds F. E. Vega and R. W. Hofstetter (Elsevier). p. 177-207. doi: 10.1016/B978-0-12-417156-5.00005-8

4. Heil, M., and Ton, J. 2008. Long-distance signalling in plant defence. Trends Plant Sci. 13:264-72. doi: 10.1016/j.tplants.2008.03.005

5. Mageroy, M. H., Christiansen, E., Långström, B., Borg-Karlson, A. K., Solheim, H., Björklund, N., et al. 2020. Priming of inducible defenses protects Norway spruce against tree-killing bark beetles. Plant Cell Environ. 43:420-30. doi: 10.1111/ pce.13661

6. Bark Beetle Outbreaks. National Science Foundation \& NBC Learn. Available online at: https://youtu.be/y7jDInfa5Y0 (accessed August 25, 2020).

7. Negrón, J. F., and Cain, B. 2019. Mountain pine beetle in Colorado: a story of changing forests. J. Forest. 117:144-51. doi: 10.1093/jofore/fvy032

8. Hlásny, T., Krokene, P., Liebhold, A., Montagné-huck, C., Müller, J., Qin, H., et al. 2019. Living With Bark Beetles: Impacts, Outlook and Management Options. From Science to Policy 8. Joensuu: European Forest Institute.

SUBMITTED: 04 September 2019; ACCEPTED: 04 August 2020; PUBLISHED ONLINE: 14 September 2020.

EDITED BY: Dominik K. Großkinsky, Austrian Institute of Technology (AIT), Austria

CITATION: Mageroy MH and Krokene P (2020) A Battle for the Forest: Spruce Castles and Bark Beetle Attacks. Front. Young Minds 8:121. doi: 10.3389/frym.2020. 00121

CONFLICT OF INTEREST: The authors declare that the research was conducted in the absence of any commercial or financial relationships that could be construed as a potential conflict of interest.

COPYRIGHT () 2020 Mageroy and Krokene. This is an open-access article distributed under the terms of the Creative Commons Attribution License (CC BY). The use, distribution or reproduction in other forums is permitted, provided the original author(s) and the copyright owner(s) are credited and that the original publication in this journal is cited, in accordance with accepted academic practice. 

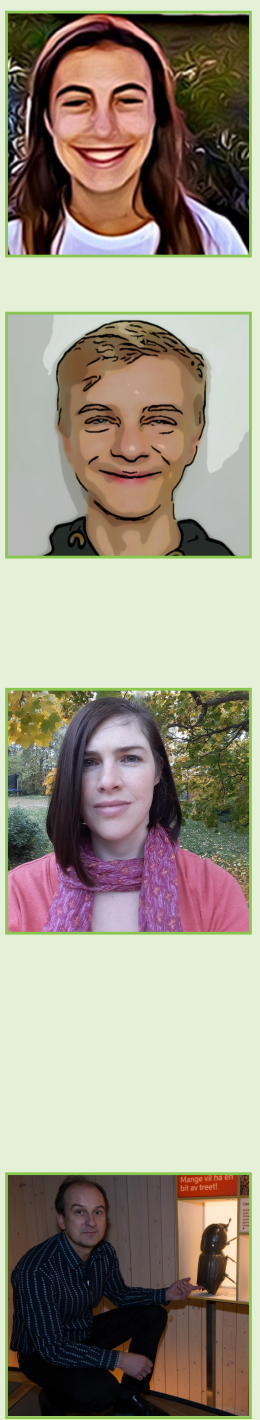

No use, distribution or reproduction is permitted which does not comply with these terms.

\section{YOUNG REVIEWERS}

\section{GWEN, AGE: 13}

$\mathrm{Hi}$, my name is Gwen, I live in the U.S. and play piano and volleyball. I am in seventh grade, and my favorite subjects are science, math, art, and Spanish. I love to read, particularly Sci-Fi novels and series (I am also a huge fan of Harry Potter). I just started working with Frontiers for Young Minds, and am very excited to continue!

\section{JUSTUS, AGE: 14}

My name is Justus, I am 14 years old and live in Germany. I play tennis, piano, and cello. In my free time I meet my friends and ride my bike. In the city I live, there is a very famous football club, which I support.

\section{AUTHORS}

\section{MELISSA H. MAGEROY}

I am a molecular plant biologist at the Norwegian Institute of Bioeconomy Research. From an early age, I have been curious about how and why thing work the way they do. I also found plants fascinating as they contribute so much to our lives: food, oxygen, shelter, medicines, etc. In my current work, I study how spruce trees defend themselves against pest by making defensive chemicals and forming memories of previous pest attacks. Not only do I find spruce trees fascinating to study, but I also enjoy walking in the spruce forest by my house and seeing, hearing, and smelling the life that abounds there. ${ }^{*}$ melissa.mageroy@nibio.no

\section{PAAL KROKENE}

I am a forest entomologist at the Norwegian Institute of Bioeconomy Research. I study conifer trees and how they defend themselves against bark beetles and pathogens. One reason I find bark beetles fascinating is that they can kill huge numbers of trees that are a 100 million times larger than themselves. The beetles do not operate alone but team up with tiny fungi called blue-stain fungi. The beetle is like a bus carrying its fungal passengers from one tree to another. In return, the fungi help the beetles breaking down tree defenses. When I am not working I like to travel and to run in the forests in Ås, where I live. 